\title{
ETHICS, PSYCHIATRY AND MENTAL HEALTH
}

\begin{abstract}
Alberto Perales ${ }^{1}$
Abstract: After delimiting the concepts of moral and ethics the author makes a conceptual difference between psychiatry and mental health. He proposes that the former is a medical specialty while the latter is built in the health concept. Psychiatric problems correspond to mental disorders that affect individual persons while mental health problems, such as underdevelopment and poverty, generalized corruption and violence affect the whole society and interfere with human development and economic growth. To mix up both concepts as if they were synonymous, especially in third world countries, leads to scientific, economic and socio-political risks that attempt against their developments as nations.
\end{abstract}

Key words: ethics, psychiatry, mental health

\section{Ética, psiquiatría y salud mental}

Resumen: Luego de deslindar los conceptos de moral y ética, el autor distingue conceptualmente psiquiatría de salud mental. Postula que la primera se refiere a una especialidad médica, mientras la segunda es ínsita al concepto de salud. Los problemas psiquiátricos corresponden a trastornos mentales que afectan a individuos, mientras que los de salud mental, tales como el subdesarrollo y la pobreza, la corrupción generalizada y la violencia, afectan a toda la sociedad e interfieren con el desarrollo humano y económico de los países. Confundir ambos conceptos como si fueran sinónimos, particularmente en países del tercer mundo, conduce a riesgos científicos, económicos y político-sociales que atentan contra su desarrollo como naciones.

Palabras clave: ética, psiquiatría, salud mental

\section{Ética, psiquiatria e saúde mental}

Resumo: Após deslindar os conceitos de moral e ética, o autor distingue conceitualmente psiquiatria de saúde mental. Postula que a primeira se refere a uma especialidade médica, enquanto a segunda é ínsita ao conceito de saúde. Os problemas psiquiátricos correspondem a transtornos mentais que afetam os indivíduos, enquanto os de saúde mental, tais como o subdesenvolvimento e a pobreza, a corrupçáo generalizada e a violência, afetam toda a sociedade e interferem no desenvolviento humano e econômico dos países. Confundir ambos conceitos como se fossem sinônimos, particularmente em países do terceiro mundo, conduz a riscos científicos, econômicos e político-sociais que atentam contra o seu desenvolvimento como naçôes.

Palavras-chave: ética, psiquiatria, saúde mental

\footnotetext{
${ }^{1}$ Instituto de Ética en Salud, Facultad de Medicina, Universidad Nacional Mayor de San Marcos, Perú Correspondence: perales.alberto@gmail.com
} 
Miguel Polo indicates that every culture, every human group structures its own way of life based on valuations upon what is good or bad, right or wrong, convenient or inconvenient, that is, it creates a collective ethos, a moral life.

This behavior, according to the author cited, is organized in our mind in two levels of thinking:

1. A pre-reflexive ethos (the morals lived, the morality) and,

2. A reflexive ethos.

The first level is the source, the second one is the dynamic force, that which brings clarity (and comprehension) to the moral language, in addition to possibilities of (moral) conflicts solution as well as concepts renovation(1).

Gradually, collective moral conducts turn, by force of habit and vicarious learning in unquestioned customs, into valuations that give us the certainty of being acting in a righteous manner, since we do what the collective does. In such a situation, human conduct — that always begins in the thinking — shall obey a pre-reflexive moral thought, not a moral reflection.

By reflection Polo addresses the thinking that takes itself as an analysis object, that evaluates its foundations as a given conduct in order to justify it before the society and oneself as an actor.

In fact, such reflexive attitude is necessary to justify and assume the responsibility of our own actions and their consequences. From this perspective, what is moral is linked to each one's (or each ones') pre-reflexive personal conduct; the ethical, to the gaining of awareness derived from the reflexive analysis that, valuing the quality of a conduct or a fact as good or bad, allows justifying or disqualifying it according to theories or cultural beliefs.

The purpose of this work is oriented to emphasize the ethical dimension in psychiatry and mental health and of their essential study object: Man.

\section{The epistemological problem: what is man?}

Focusing the problem from a more complete perspective obliges to include all the dimensions that configure the Man as a human being. To such purpose, the proposal by José Ortega y Gasset complies well with such requirements. In "Meditaciones del Quijote", 1914, he proposes the following definition: "I am I and my circumstance, and if I do not save it I do not save me" (2).

Regarding this term, circumstance, the Spanish Royal Academy Dictionary, in its 23rd, edition, 2014, provides us with the following meanings:

"From lat. circumstantia. 1. f. Inflected form of time, place, mood, etc., that is united to the substance of a fact or saying. 2. f. Quality or requisite. 3. f. Group around somebody; the world concerning somebody's world'.

It refers, thus, to what surrounds the "substance", the ontological being, that is, its personal world, as the ontological being perceives, experiences and gives meaning to its personal world.

Man yields the maximum of his capacity when he acquires the full conscience of his circumstances. For his circumstances the Man surpasses his own corporeity, it is not solely himself, it is himself and his world (human or not). His circumstance (world) not only influences in the Man but it is rather a part of him (of his substance), and he, in turn, is a part of his world. The influence is reciprocal and of mutual necessity. This is why Ortega wisely advices "and if I do not save it I do not save me". That is, that the Man must take care of his circumstance, not only because of an ethical imperative but also because of the need of survival, as, in the event of not saving his circumstance - for instance his ecological surroundingshe shall not save himself. It is understood, from this perspective, that morals and ethics are not mere philosophical exercises but rather survival mechanisms that the Man has developed since he understood that his existence depends on coexisting with the other in collective cooperation, that is, in solidary cooperation. That the care of the other and viceversa, the being taken care by the other, enhances the probabilities of survival of both. Moral conscience is thus forged in fundamental ethical parameters expressed by thinkers through centuries: "Do not do to others what you do not wish them to do to you". 
For the same reasons, the pre-reflexive moral conduct and its ethical reflexive perfecting, constitute, as we have mentioned, a social mechanism of defense to protect the species. When the humanity in whole understands this vital necessity and exercises it with responsibility, the Man would have given a great step towards his long term survival and transcendence.

Moving this view to the medicine field, the total circumstance of the physician in the Medical Act is the patient, whom, therefore, the physician must "take care of" in order to "save" him/her. If doing it, the physician will be saved as well, as a person and as a professional. On the contrary, if failing this moral and scientific obligation, the physician will harm himself affecting thus his own humane and professional flourishing. A poorly treated patient may sue the physician; a well-treated patient may love, thank the physician, and decisively contribute to his professional prestige. Let us remind ourselves that with our science we diagnose, heal and/or relieve; with our art, we bring care and support. And that art, that attitude and disposition to service settled in our medical vocation and instrumented by the right technique, constitute, in essence, the dynamic core of all medical act, particularly in psychiatry and mental health.

\section{Psychiatry and mental health}

The necessary difference between these two concepts must be justified because considering mental health almost as a synonym to psychiatry facilitates its relegation in the Health budget as it may not compete with other medical pathologies, such as children malnutrition or mother mortality, so to cite a few examples, more dramatic to society. It seems understood as if we were speaking of a psychiatry "in small" and a psychiatry "in a greater proportion", without noticing that when subsuming them in a sole phenomenon we homogenize not only their problems but also their methodologies of study, their management techniques and their prevention approaches, as if they were the same. This approach's consequences, particularly for underdeveloped countries, are very negative. They relinquish to what they need most, to understand and use the important association between mental health (as a difference of psychiatry) with human, society and national development.

\section{What is psychiatry?}

The classic definition is "the medical specialty or science that deals with the origin and treatment of mental diseases".

If it is necessary to evaluate the dimension of psychiatric problems in a certain country, commonly we resort to the prevalence measurement of mental disorders or to the global conclusions inferred from such measurements. For example, the Director to the Pan American Health Organization, in the 2010 Regional Conference of Mental Health informed the world the following: "It is estimated that one of four persons will suffer from a mental disorder in the course of his/her life, and that one of four families has, at least, one member affected with one or more mental disorders"(3).

In Peru, for example, the Mental Health National Institute has published, among other measurements, the results of its second survey in Metropolitan Lima(4) (See Chart No 1).

Chart no 1: Psychiatric problems in Peru. Specific psychiatric disorders P.V. (CIE-10).

Adult population of Metropolitan Lima and Callao (2012).

\begin{tabular}{|l|l|l|l|}
\hline Type & Total \% & M\% & F\% \\
\hline Depressive Episode & 17.2 & 12.5 & 21.6 \\
\hline $\begin{array}{l}\text { Prejudicial/dependence } \\
\text { Consumption OH }\end{array}$ & 7.5 & 13.5 & 1.8 \\
\hline T.E.P.T & 5.1 & 3.4 & 6.7 \\
\hline General Anxiety & 3.0 & 2.6 & 3.3 \\
\hline Social Phobia & 2.2 & 2.0 & 2.4 \\
\hline
\end{tabular}

The Depressive Episode may be appreciated as the most prevalent disorder and the Post Traumatic Stress Disorder emerges as an important pathology contrarily to earlier times.

We refer to the mental disease problem, subject matter of psychiatry. To handle these problems this medical specialty knows how to act, it counts with research and defined methodologies of intervention, even though success not always accompanies its efforts. 


\section{What is mental health?}

WHO has recently updated the definition of Mental Health as "a state of well-being in which every individual realizes his or her own potential, can cope with the normal stresses of life, can work productively and fruitfully, and is able to make a contribution to her or his community"(5). However in daily professional practice things seem to be different.

Moll, for example, has studied the representations of mental health in employees of two mental health institutions. Although her sample is rather small, her findings coincide with the daily experience of those of us who work or have worked in this type of establishments constituting good hypothesis for more systematized future investigations. This author concludes that: "the mental health staff interviewed does not have a clear concept about: what is mental health?.. Furthermore, a social discriminatory representation of the mental patient is appreciated, that may affect the quality of the professional relationship with the patient"(6). In other words, if the staff does not know what mental health is -the essence and purpose of their institution- the risk that the service offered would be of low quality will exist, not exempted from social discriminatory contamination towards the mental patient.

In order to understand what Mental Health is, we must first understand the concept of Health.

\section{Definition and concept of health}

"Health is a state of complete physical, mental, and social well-being and not merely the absence of disease or infirmity" (7).

Health constitutes a fundamental right, without any restrictions, of all human beings, even though in order to satisfy such right it is worth to emphasize the obligation and the responsibility of the human being in the self-care. In other words, there is no State able to cover all the health needs of its population unless every one of its members assumes the duty and responsibility of the selfcare and self-protection.

As a biological, psychological, social and spiritual phenomenon, health is conditioned by the moment of historical development of every society. For this reason, the governments' moral obligation (as a politic mechanism of social defense) is to keep the general health of the people as a fundamental condition for world peace and security. In such sense, the adequate cooperation between the State and the people is essential.

In this perspective, we understand that the concept of mental health is inherent to the most general concept of health, representing its psychological and social dimensions. Consequently, to define Mental Health would not be necessary although it has been a numerous times repeated effort without success. In practice, if we assert that a human being enjoys good health we are including -without specifying it- that it enjoys good mental health as well.

As clear is the inclusion of the mental health concept in the health concept that the former's WHO updated definition (see above) (5) applies perfectly to what we understand as Health: "a state of well-being in which every individual realizes his or her own potential, can cope with the normal stresses of life, can work productively and fruitfully, and is able to make a contribution to her or his community". In other words, we are referring essentially to the same notion.

On the other hand, we assert together with Casas, that: "The whole and holistic concept of health is based upon an ethical consideration, that is, the right of every human being to have an opportunity to live a healthy (and happy) life. Hence, equity and social justice are the basic concerns to achieve health and human development" (8).

Finally, both concepts are supported on the wholeness of the human being, since there is no health or mental health without the normal development of his biological dimension, in this case, his brain.

\section{How is mental health expressed? Mental health problems in Peru}

As opposed to psychiatric problems that, as we have mentioned are expressed as mental disorders in individual persons and collective groups, 
mental health problems are multi-sectors problems of great magnitude that compromise society and affect nations development. There is no way of comparing their importance or confusing the concepts into a single one. Furthermore, it may be asserted that a good level of mental health guarantees the population's well-being through solidarity and collective work. The so called German and Japanese "economic miracles" post second world war, are clear examples of that. Of how people united for a strong mental health (solidary mental attitude before life) may reconstruct countries almost totally destroyed. From such facts we may infer that the Health budgets oriented towards psychiatry develop a humanitarian and scientific task to recover mental health and productivity of a large number of affected individuals by mental disorders. On the contrary, if the national budget (multi-sectors) invests in mental health it shall push forward the development and the entire population productivity (healthy and affected) and, thus, of the whole nation.
If we ask ourselves now, which are the main mental health problems, for example, in Peru, what is equal to asking: which are the multi-sectors problems that affect the Peruvian population and attempt against its national development? We would mention that in 1989 , summarizing our experience in the subject, we pointed out the following three(9):

\section{Under-development and Poverty \\ 2. Generalized Corruption}

\section{Violence}

Surprisingly today, after 25 years, the multi-sectors problems referred to are still the same (See chart No 2)

In chart No 2, the Metropolitan Survey of Mental Health of Metropolitan Lima (4) emphasizes in the first place delinquency (which is a type of violence); in second place, corruption; and in third and fourth place unemployment and poverty (that use to be interconnected).

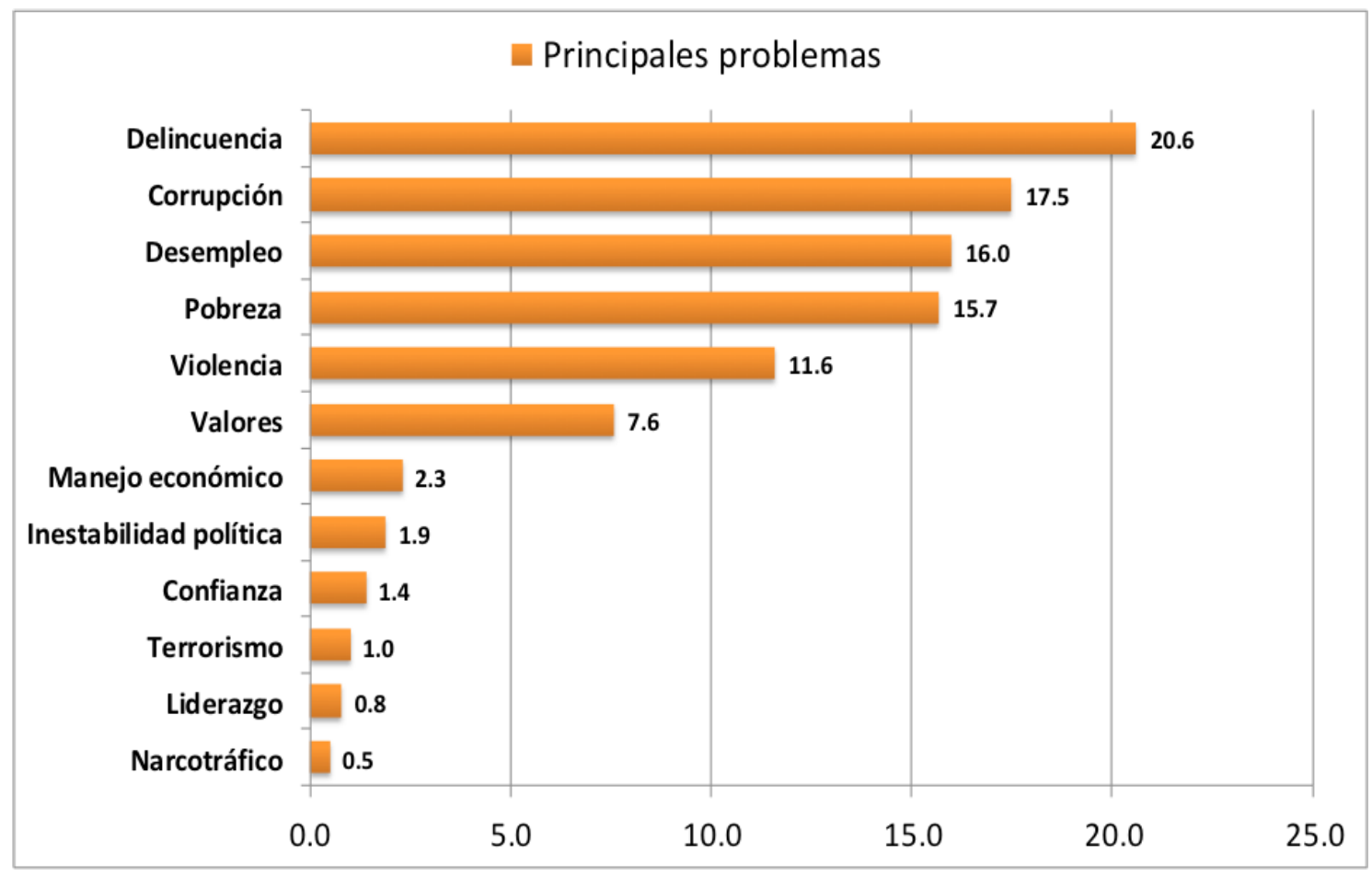

Chart n. 2: Main problems of Peru perceived by the adult population of Metropolitan Lima and Callao 2012. 
Why do we place underdevelopment and poverty as a mental health problem?

In order to be able to develop the everyday activities a person needs to ingest 2119 calories per day. The monthly average cost, in 2014, of these calories (household food basket) was 161 soles (Peruvian currency), which if not satisfied, marks the extreme poverty level. On its side, the poverty condition is measured as the family inability of generating an income that allows satisfying the monthly average cost of the household food basket (S/.303 soles monthly)(10).

Poverty is not only an economical phenomenon. From the mental health angle it is added or not to such economical lack, a mental attitude towards life and the challenges that any human being must face in the fight for survival. From this view, we understand that there are two types of poverty:

a) Transitory and without poverty culture. These people are economically poor for different reasons. However, personally they keep, despite the disadvantages, an energy of thought with persevering aspiration to overcome such situation, as a housewife mother told us, "anyways we will make it". They face the misery of their existence with battling, vigorous and courageous spirit, stimulated not by a wish of personal wealth but by the love for their children, whom they do not want to see suffering what they have been through. A living example in Peru is the internal migration phenomenon, particularly intense during the terrorism that beat down the country in the period of 1980 -2000. A good number of those persons, despite the negative circumstances, lifted their families out of economical poverty with earnest work and entered into a thriving middle class that impelled and impels the country growth in what Hernando de Soto, E. Ghersi y M. Ghibellini called "The Other Path" in contrast with the "Shining Path" that affected the country in the opposite sense(11).

b) Chronic and with poverty culture. Differing from the former, these people constitute chronically poor populations. Their attitude towards life is looser and whiny. The government and "the rich people" are guilty for their disgrace. They live in the poor neighborhoods of the city for gen- erations, without any active behaviors for social rise. Their whole existential attitude is pessimistic and of poor self-confidence. Their aspirations are passive, linked to what life and chance may give them. They do not generate wealth, but rather they consume it. They contribute to keep the nation under developed.

In brief, poor population with no poverty culture sooner or later will generate wealth, will step out of their economical poverty and will contribute to the nation development. The aid they need most from the government is technical training, economical credit and job opportunity. In this case the aid policy must be oriented directly to the adults involved. In Peru, many of these adults have created their own labor opportunities through one person or family informal businesses. On the contrary, poor population with a poverty culture requires a different aid policy, of long term and more oriented to the education of their children with the purpose of breaking the inter-generations transmission of poverty culture.

\section{Violence}

Guerrero mentions that in the health sector, violence:

- Is the first cause of death, 120,000 homicides per year.

- Is responsible for the loss of 3 days/person a year.

- Causes between 30-60\% of all medical appointments assisted in Emergency Units.

- Is associated to alcohol abuse in $60 \%$ of cases(12).

The Inter-American Development Bank and the World Bank have pointed out violence and insecurity as the greatest obstacles for the development of the Americas Region, given that 14.2 $\%$ of the GDP (168 billions of dollars) are lost or transferred for that reason; and $1.9 \%$ of the GDP is lost in human capital. Such percentage equals all the regional expense in elementary education(13).

In Peru the problem is complicated by the presence of organized crime. The population per- 
ceives delinquency as the priority problem that the government must resolve. Before the new elections the candidates place citizen's security as the first offer to gain votes. We will not extend in the topic on the other type of violence but will only mention that domestic violence has become in our country a public health problem, generator, additionally, of many other psychiatric pathologies. To fight against it requires, once more, not only action by the Health Sector, but also coordinated inter-sectors policies as any mental health problem that affects the country development demand.

\section{Generalized corruption}

Sanjeev Gupta, Hamid Davoodi, Rosa AlonsoTerme conclude that the high levels of corruption in a country are associated directly to the increase of poverty and the social inequalities of the population(14).

Niki A. Den Nieuwenboer, Muel Kaptein study the mechanisms of corruption in organizations. They find three dynamic axes which they name: of divergent rules, of pressure and of opportunity (15).

As one of the visible mechanisms that back up corruption in time is the establishment of networks or systems whose elements support mutually seeking impunity. Peruvian society struggles with a justice system in which -given the scandals published by the press- only a few believe. Even though the suitability of certain judges and prosecutors are recognized, the opinion of the majority is that the judicial system is corrupt. From there to the wish to make justice by oneself in the style of Fuenteovejuna, "all to one", is a short way. Thus, it is no surprise that in a recent public survey the majority of the Peruvian population answered to the question: What to do before citizen insecurity? With the expression "grab your crook". And to the following question: Why? They answered: "they are all in cahoots", meaning that all authorities are part of the same corrupt system. That is, "do not expect Peruvian justice to catch the delinquent and punish him, grab him yourself and punish him yourself". It is neither surprising that the police has had to intervene in some cases in order to avoid the lynching of a thief caught in- fraganti by a community. Finally, in the same survey, to the question: What to do to reactivate the economy? The most frequent answer was to fight corruption efficiently, far over those answers that offered taxes reduction or labor reforms ${ }^{2}$.

In summary, the population perceives corruption as an organized system. And the institutions made to fight it, such as the Judiciary, the Congress of the Republic and the Police, as the most corrupt.

\section{Psychiatry as an ethical institution}

The democratic system which we belong to is founded in the freedom to elect our governing authorities, in the understanding that such authorities, elected that way, shall exercise the power giving priority to the people well-being, with equal rights and within an ethical and legal framework of justice.

In order to achieve such purpose democracy must take support in organizations that are ethically solid. One of those organizations is the scientific institution. In the health field, the institution that has the greatest influence on human behavior is psychiatry, which must take care of the ethics in order to comply properly with its scientific responsibilities.

Whitaker and Cosgrove, mention in a recent publication that numerous institutions fail to comply with their moral obligations and say about the United States: "That the Wall Street greed almost drove our public bank system to a collapse. Congress is in debt with special interests. We have seen religious institutions, the Catholic Church, to fail systematically in protecting children from sexual abuse." And they add: "What these scandals have in common is that they cause social damage, they erode public faith in the institutions and, thus, they weaken the democratic essence of society" (16).

Marcia Angell, points out in her criticism(17):

- The vast use of psycho-active drugs in children, including some that the FDA has not yet approved for such age group.

\footnotetext{
${ }^{2}$ Torres A. Encuestas top, 2015. El Comercio, domingo 27 de diciembre de 2015.
} 
- That in USA, one of every 10 children takes stimulating medication for Attention Deficit Disorder and hyperactivity.

- And 500,000 children receive anti-psychotic medication.

Daniel Carlat, referring to his own professional exercise, comments that in a patient clinical attention, if he uses a pharmaceutical therapeutic approach he is able to assist three patients in an hour, with earnings of $\$ 180$ as a payment by the insurance company, while in a psychotherapeutic approach, time would only be enough to assist one patient, with an earning of less than $\$ 100$. Carlat ends accusing psychiatrists of treating only symptoms instead of causes, supported in the apparent scientific strictness of the American diagnosis system, the DSM(18).

On the other hand, the intervention of third parties in the every time more evident "health market" orientates their purpose to a commercial aim with negative changes in the Medical Act, in general, and in the psychiatric interview, in particular. The patient is not the patient anymore, is a client and acts as a consumer ready to, every time more, demand and claim — even by the legal way - for the product quality.

We may assert that the risk of dehumanization of the psychiatric practice is high. The Person in the patient is forgotten(19). And it is forgotten, likewise, that Psychiatry that does not center in the Person is not Psychiatry3.

All the above described implies changes in the ethics of the psychiatric practice that affects the potency of the Therapeutic Alliance. As we know, the dynamics of this interaction demands both partners, physician and patient, to work in reciprocity in order to overcome the health problems that the latter brings to the medical appointment. The so called Faith in the doctor (a factor clinically recognized as a therapeutic reinforcing) and the unspecific factors that Jerome Frank described(20) are being diluted to be replaced by faith in science and technology. This way the art of psychiatry is threatened to be "depersonalized" turning into a sophisticated technique that may

${ }^{3}$ Paraphrased reflection of the comment by Peruvian Academician Alberto Cazorla "Medicine that is not centered in the person is not medicine". be procured by computers applying specific questionnaires in replacement of clinical anamnesis, and whose answers, by means of established algorithms, would conduct to the automatic request of auxiliary exams to conclude the diagnose and the therapeutic recommendation that the medicine by evidence may propose. Psychiatry of the future would be, thus, able to assist a significant volume of the population, with the capability to treat every time more diseases, but every time less patients. With this, the most important thing about psychiatry and its therapeutic art is forgotten: to seize the opportunity that the break in the psychic health brings to reduce, control or overcome illness by pharmacological, biological and other means, and at the same time to promote the patient's emotional, social and spiritual maturity by means of the therapist-patient emotional relationship, psychotherapies as well as family, psychosocial and other interventions. Treated in this complete facing approach, the patient may arise out of the disease understanding the dynamic of his illness and acquiring better and more mature defense mechanisms that will help him in a better adaptation to the circumstances(21).

\section{Conclusions}

Psychiatry is a medical specialty. It is linked to the abnormal conduct of the man. It is exercised by specialist physicians. Its problems affect the individual and its environment.

Mental health is inherent to health. It is linked to the human development. It is a multi-disciplines and multi-sectors concept. Its problems affect society and the nation development.

We propose to include among the subjects of Mental Health study: under-development and poverty, generalized corruption, violence, ethics and dehumanization in psychiatry. All of them characterized as problems, besides scientific, moral of our society.

Government policies should not confuse psychiatry and mental health as synonyms since, if doing so, the potentialities of human and economic development that mental health has for the country would be wasted. 
Psychiatry is in jeopardy of dehumanization and bears negative influences derived from the "health market" that are eroding its ethics.

\section{Final words}

In spite of all the scientific progress and efforts of psychiatry in resolving the problems of this specialty, that mark a promising path with the contribution of genetics, neuroscience, clinicepidemiologic science and social science, we are convinced that the solution of the mental health problems -linked to the human and the people development- is not in the hands of the medical science but rather in the hands of the government political levels which we must strive to inform and illuminate upon the conceptual differences between psychiatry and mental health, and accept that in this task, Rudolf Virchow is right when he expressed that: "Medicine is a social science and politics is nothing more than medicine in a larger scale"
But in addition to that and no less important, is that the physician should return to being a physician. That his conscience awakes and functions to a level of critical thinking in order for the moral reflection, that is, ethics to appear. That the psychiatrist - who works with the most human part of the man- reassumes back the quality of moral example that allows the population to rescue the value of our profession as a living example of ethical morality.

\section{Acknowledgment}

To Dr. Javier Saavedra, for providing important data from the Peruvian Mental Health National Survey, Lima 2012. 
Ethics, psychiatry and mental health - Alberto Perales

\section{References}

1. Polo M. Los lenguajes de la ética. Lima (Peru): Editorial Mantaro; 2006.

2. Ortega y Gasset J. Meditaciones del Quijote (1914). In Obras Completas de José Ortega y Gasset. (6th Edition), 1. Madrid: Revista de Occidente; 1963: 322.

3. Organización Panamericana de la Salud. Conferencia Regional de Salud Mental. Panamá; 2010.

4. Instituto Nacional de Salud Mental. Estudio Epidemiológico de Salud Mental en Lima Metropolitana y Callao, Replicación 2012. Informe General. Anales de Salud Mental 2013; Supplement 1, Volume 29: 1-392.

5. World Health Organization. Mental health: a state of wellbeing. Available from: http://www.who.int/features/factfiles/ mental_health/en/

6. Moll S. Representaciones de la salud mental en trabajadores de dos instituciones especializadas de Lima Metropolitana. Revista de Psicología 2013; 31(1). On-line version ISSN 0254-9247.

7. WHO. Preamble to the Constitution of the World Health Organization as adopted by the International Health Conference, New York, 19-22 June, 1946; signed on 22 July 1946 by the representatives of 61 States (Official Records of the World Health Organization, no. 2, p. 100) and entered into force on 7 April 1948. Available from: http://www.who.int/about/ definition/en/print.html

8. Casas JA. Entorno de la salud y desarrollo humano en la región: En Pellegrini A, Macklin R. (Eds.) Investigación en sujetos humanos. Santiago de Chile: OMS/OPS; 1999: 115-122.

9. Perales A. Concepto de Salud Mental. La experiencia Peruana. Anales de Salud Mental 1989; 5(1,2): 93-101.

10. INEI. Evolución de la pobreza monetaria en el país al 2014. Lima, Peru; 2015. Available from: https://www.inei.gob.pe/ media/cifras_de_pobreza/evolucion_pobreza_2014.pdf

11. De Soto H, Ghersi E, Ghibellini M. El otro sendero. Lima: Editorial El Barranco, Instituto Libertad y Democracia; 1986.

12. Guerrero R. Violence is a health issue. Editorials. Bulletin of the World Health Organization 2002; 80(10): 767.

13. Londono JI, Guerrero R. Violencia en América Latina: epidemiología y costos. In: Londońo JI, Gaviria A, Guerrero R. (Editors). Asalto al desarrollo. Violencia en América Latina. Washington DC: Inter-American Development Bank; 2000.

14. Gupta N, Davoodi H, Alonso-Terme R. Does corruption affect income inequality and poverty? Econ. Gov. 2002; 3: 23-45.

15. Niki A, Nieuwenboer D, Kaptein M. Spiraling Down into Corruption: A Dynamic Analysis of the Social Identity Processes that Cause Corruption in Organizations to Grow. Erim Report Series Research in Management, December 2007. ERIM Report Series reference number: ERS-2007-086-ORG. Available from: http://hdl.handle.net/1765/10772

16. Whitaker R, Cosgrove L. Psychiatry under the influence. Institutional corruption, social injury, and prescription for reform. N.Y.: Palgrave Macmillan; 2015.

17. Angell M. The Illusions of Psychiatry. The New York Review of Books, July 14, 2011. Available from: www.yoism.org

18. Carlat D. Unhinged: The trouble with Psychiatry. A Doctor's revelations about a Profession in crisis. N.Y.: Free Press; 2010.

19. Mezzich JE. Psychiatry for the Person: articulating medicine's science and humanism. World Psychiatry 2007 Jun; 6(2): 65-67.

20. Frank DJ. Frank BJ. Persuasion and Healing: A comparative study of psychotherapy. Baltimore: The Johns Hopkins University Press; 1993.

21. Perales A, Leon R, Mezzich JE. Un Modelo de normalidad en salud mental y diagnóstico multiaxial. Anales de Salud Mental 1989; 5(1-2): 11-28.

Received: March 16, 2016

Accepted: March 31, 2016 